Article

\title{
What Form of Visibility Affects Earnings Management? Evidence from Italian Family and Non-Family Firms
}

\author{
Giovanna Gavana ${ }^{1,+(\mathbb{C})}$, Pietro Gottardo ${ }^{2,+}$ (i) and Anna Maria Moisello ${ }^{2, *,+(\mathbb{C})}$ \\ 1 Department of Economics, University of Insubria, 21100 Varese, Italy; giovanna.gavana@uninsubria.it \\ 2 Department of Economics and Management, University of Pavia, 27100 Pavia, Italy; pietro.gottardo@unipv.it \\ * Correspondence: annamaria.moisello@unipv.it; Tel.: +39-382-986247 \\ + These authors contributed equally to this work.
}

Received: 7 January 2019; Accepted: 27 February 2019; Published: 5 March 2019

check for updates

\begin{abstract}
This paper addresses the issue of financial communication quality by studying the determinants of earnings management practices in family and non-family businesses. Previous literature has highlighted the effect of a company's size, as a form of visibility, on earnings management practices. This study focuses on the analysis of the relationship between different forms of visibility - exposure to financial press, proximity to the consumer, size of assets, sales and firm age-and earnings quality. The results show that the forms of visibility taken into consideration have a different effect on earnings management practices. Furthermore, they show that family businesses are less likely to resort to these unethical practices, especially in the presence of financial press exposure and proximity of the business to the consumer.
\end{abstract}

Keywords: earnings management; family firms; visibility

\section{Introduction}

Over the past twenty years, literature has extensively investigated the phenomenon of earnings management, given the potential harm that this unethical practice entails for a company's stakeholders, in particular for investors (Chih et al. 2008). The extent of the impact of this phenomenon is evidenced by the financial scandals that marked the beginning of this millennium, such as Enron, Parmalat and WorldCom (Tiscini and Di Donato 2006). Accruals-based earnings management meets the objective of influencing information that is relevant to investors (Walker 2013) or to contractual reasons such as compliance with financial covenants (Becker et al. 1998) or the achievement of the performance requirements set by the directors' remuneration systems (Bergstresser and Philippon 2006). Earnings management can also be perpetrated in order to reduce the profit for the year with the aim of reducing the tax burden for the period (Goncharov and Zimmermann 2006) or to reduce dividends and increase self-financing (Abdolmohammadi et al. 2010). Earnings management can also be carried out in order to smooth out the variability of profits, change the market's perception of the risk of investing in company securities and, in this way, reduce the cost of capital (Graham et al. 2005). According to the definition by Schipper (1989), earnings management corresponds to the concept of "disclosure management." This is intended as the intentional intervention on the external reporting process with the aim of obtaining a private benefit.

The literature has investigated different areas of research on the subject. The quality of earnings has been investigated in connection with share issues and in relation to debt, concluding that companies implement earnings management to influence investors' appreciation or to anticipate market behaviour (Rangan 1998; Teoh et al. 1998), to avoid external financiers' violating covenants or interference in 
governance (Prencipe et al. 2008). Earnings management has been studied in relation to different governance characteristics, such as independence and board size (Beasley 1996; Davidson et al. 2005; Klein 2002; Kao and Chen 2004; Xie et al. 2003), existence and independence of the audit committees (Bédard et al. 2004; Jaggi and Leung 2007), ownership concentration (Yeo et al. 2002) and presence of institutional investors (Chung et al. 2002; Rajgopal et al. 2003). More recently, literature has taken into account the nature of ownership and has addressed the issue of earnings management in family businesses. The results, although sometimes conflicting, show a different propensity to manipulate financial information in family and non-family businesses (Prencipe et al. 2008; Jaggi et al. 2009; Stockmans et al. 2010; Achleitner et al. 2014; Chi et al. 2015; Gottardo and Moisello 2019). The manipulation of profits is an unethical behaviour and ethics significantly influence a company's reputation (Mella and Gazzola 2015). Recent studies suggest that family businesses are more sensitive to the potential reputational effects of earnings management than non-family businesses; they are more likely to distract attention from this unethical practice by showing their social and environmental commitment through sustainability reporting and this behaviour is significantly accentuated when companies have high visibility in terms of size (Gavana et al. 2017a). This article analyses the effect of different forms of visibility—size, financial press exposure, proximity to consumer and firm age-on earnings management in family and non-family businesses, studying a sample 172 non-financial companies listed on the Italian stock exchange for the period 2007-2017.

The determinants of the quality of the accounting information of family businesses are of particular interest given the diffusion and economic relevance of this ownership structure all over the world (La Porta et al. 1999) and the potential impact of the manipulation of profits on shareholders as well as for other types of stakeholder. Italy is a significant area of study given the prevalence of family control between both listed and unlisted companies (Corbetta and Minichill 2005).

The article develops as follows: paragraph two introduces the theoretical framework; the third analyses the peculiarities of agency conflicts in family businesses; the fourth presents the results of the studies on earnings management in family businesses; the fifth presents the methodology and data; the sixth analyses and discusses the results and the seventh concludes by highlighting the limits and possible future developments on the topic.

\section{Theoretical Framework}

\subsection{Agency Conflicts and Earnings Quality}

Earnings management literature has assumed Agency Theory as its main theoretical framework, since the manipulation of accounting information can be interpreted as the result of agency conflicts (Paiva et al. 2016). The different motivations that lead to earnings management derive from different types of conflict. Agency Theory (Jensen and Meckling 1976) is based on the separation of a company's ownership and control, typical of companies with widespread capital. This results in conflict and information asymmetry between the owner (owner) and the management (agent). The agent tends to act in his own interest in place of the principal, giving rise to moral hazards and adverse selection (Hölmstrom 1979; Jensen and Meckling 1976). This type of agency conflict may result in upward earnings management in order to achieve benchmarks on which managerial incentives are based or in downward earnings management when the economic result for the year exceeds the aforementioned benchmark, the future performance is uncertain and management moves part of the profit to the following year to ensure the achievement of the objectives. The second type of agency conflict is linked to ownership concentration and consists in the contraposition of interests and in information asymmetries between majority shareholders, who control management decisions and minority shareholders (Villalonga and Amit 2006). This type of conflict is linked to downward earnings management practices aimed at reducing the distribution of dividends and increasing a firm's net self-financing in order to avoid the use of the external equity financing that can dilute the owning-family's control (Achleitner et al. 2014). 
A third type of agency conflict arises between shareholders and debt financiers (Mauer and Sarkar 2005). In particular, the former, if they have diversified portfolios, have incentives to expropriate the latter's' wealth by implementing asset substitution operations, investing in very risky projects in the expectation of high expected returns (Jensen and Meckling 1976). Debt capital lenders tend to anticipate this behaviour by demanding high remuneration. Agency conflicts between shareholders and loan capital lenders can generate upward earnings management to contain the cost of debt or avoid interference in administration by external lenders.

A fourth type of agency conflict occurs between the (principal) state and the firm (agent). The state requires private enterprise to satisfy the needs and aspirations of citizens directly, through the production of goods and services and indirectly, through the production of tax revenues. The principal and the agent have opposing interests in relation to the tax revenue and there is an information asymmetry. This conflict generates downward earnings management with the aim of reducing the taxes that the company will have to pay for the income produced.

Agency conflicts present different characteristics in non-family and family businesses. These conflicts are influenced by the specific objectives pursued by the latter. In fact, family businesses are directed not only to achieving financial but also non-financial goals, summarized fairly recently in the literature with the concept of socioemotional wealth (SEW) (Gómez-Mejía et al. 2007; Gómez-Mejía et al. 2011). This refers to the complex of non-financial returns, represented by emotional values, that the family derives from the control of the business and which deeply influence the agency conflicts in this type of company (Chrisman et al. 2004). The desire to preserve the stock of affective values invested in the business and the flow of emotional returns derived from it (Chua et al. 2015), affects managerial decisions, a firm's capital structure and the corporate governance of family businesses. This makes them significantly different to non-family firms (Gómez-Mejía et al. 2011). Different dimensions determine the non-economic returns that the family derives from the business (Berrone et al. 2012). The first is family control and influence on the firm. On the one hand, the level of control influences the importance of non-financial objectives in the firm's decision-making processes and, on the other hand, the power of the family to direct business decisions towards maximizing these objectives (Zellweger et al. 2011). The control of the business is, in itself, a source of emotional value as it confers status and visibility to the owning family. It is linked to the deep sense of identification that family members feel with the business, which therefore represents the image of the family in society. Family businesses are therefore reluctant to open their equity capital to external investors, even when the company's control is not at risk (Romano et al. 2001). Family members bring their emotions and emotional ties to the company and tend to develop lasting links with employees, not family members and make them part of a sort of extended family. This type of link is also developed with other stakeholders, such as suppliers and lenders. Deep social ties are also developed with the community where the company operates, thus satisfying family members' need to belong and to be socially recognized (Astrachan and Jaskiewicz 2008). In this perspective, the dynastic succession of the business is the means to preserve the family's ties with it and, in doing so, pass on its values and prestige through future generations (Berrone et al. 2012).

These dimensions have an effect on the different types of agency conflict. The owner's control of the company allows the family to designate one of its members as CEO or indirectly influence the executive's work by appointing the members of the board of directors. Ownership concentration increases the principal ability and incentive for monitoring (Shleifer and Vishny 1986). The incentive is greater in family than non-family companies because there are both financial and emotional returns related to this activity. Furthermore, the family has deep links with the business: its members know its characteristics and this leads to a reduction in information asymmetries. The principal agent conflict is less strong in family than non-family businesses (Anderson and Reeb 2003a) as it is moderated by the different dimensions of socioemotional wealth. These act in different ways on the conflict between majority shareholders-i.e., family members-and minority shareholders. As highlighted by Gómez-Mejía et al. (2007), the family may take decisions that mean reductions in company performance 
in order to maintain control, to the detriment of the minority shareholders who are interested in a financial return on their investment. On the other hand, the profound sense of identification between the family and the business implies, for the former, a great attention to the reputation of the latter, moderating behaviours that could jeopardize it, just like operations aimed at expropriating the wealth of minority shareholders (Gottardo and Moisello 2019).

The different aspects of SEW can also have different effects on conflicts between shareholders belonging to the family and debt financiers. The intention to pass on the business to future generations gives the business a long-term outlook, reduces the appetite for entrepreneurial risk (Gómez-Mejía et al. 2007; Gómez-Mejía et al. 2011) and limits asset substitution practices that could harm the interests of lenders, resulting in prudent management of the capital raised in the form of debt (Carney 2005). Furthermore, the bonds of trust that the business develops with its stakeholders translate into lower agency costs, as evidenced by lower debt costs (Anderson et al. 2003) and by the less stringent contractual clauses imposed by lenders to family businesses compared to non-family firms (Hillier et al. 2018). Furthermore, the propensity of the family to provide personal guarantees to banks constitutes an additional incentive to respect the contractual terms and aligns the interests of shareholders belonging to the family with those of external financiers (Steijvers et al. 2010).

The fourth type of conflict, between the company and the state, generated by an opposing interest in the amount of the taxes charged to the company, assumes particular characteristics in family businesses. On the one hand, the huge shareholding stake held by the family increases the benefit deriving from the reduction of the tax burden through aggressive operations such as earnings management. On the other hand, the high concentration of ownership and the long-term time horizon heighten the reputational damage linked to involvement in tax-related lawsuits and family businesses, given the importance of non-financial objectives, ceteris paribus, have a low tax aggressiveness compared to non-family companies (Chen et al. 2010). The sense of identification between the family and the business implies the fear that damage to company image affects the family name (Berrone et al. 2012). Empirical research suggests that family businesses, given their concern for reputation, are particularly attentive to preventing social problems (Dyer and Whetten 2006) and have proactive behaviour towards stakeholders (Berrone et al. 2010). The protection of the socio-emotional returns that the family derives from the business moderates the agency conflict between state and business as it encourages behaviour that meets stakeholders' expectations (Cruz et al. 2014), a group whose needs and aspirations can partly be satisfied with a company's tax contribution.

\subsection{Earnings Management: Empirical Evidence on Family Firms}

The empirical literature has investigated the issue of the quality of profits in family businesses with mixed results. Wang's study (Wang 2006) indicates a negative relationship between family ownership and accruals-based earnings management because of the reduced weight of the first-type agency conflicts that weigh on family businesses. Yang (2010) reaches different results, highlighting the negative effect of second-type agency conflicts on earnings quality. Consistent with this study, Achleitner et al. (2014) show that family businesses have a greater propensity than non-family firms to carry out accounting manipulations aimed at compressing profits in order to retain more resources within the company and reduce the need to find external capital.

The study by Prencipe et al. (2008) indicates that family and non-family businesses show a similar aptitude for manipulating profits through the capitalization of research and development costs aimed at avoiding covenant violations. Stockmans et al. (2010) show that the desire to maintain a firm's control is stronger for first generational stage family firms and in those managed by the founder compared to family businesses run by descendants or professional managers; for this reason, the former are more likely to manipulate profits so as to hide reductions in performance that may induce covenants or interference on the board by debt capital lenders.

Other studies show that the independence of the board has a positive role on disclosure quality but this effect is mitigated by family control since even independent directors tend to act in line with 
the interests of the controlling family (Prencipe and Bar-Yosef 2011; Cuadrado-Ballesteros et al. 2015). On the other hand, there is evidence that companies characterized by a large number of independent directors have lower quality profits (Tiscini and Di Donato 2013). Literature provides evidence of a better earnings quality for companies controlled by the founding family compared to those acquired by a family after the constitution, because the greater sense of identification between family and business discourages unethical practices that may compromise the reputation of both (Pazzaglia et al. 2013). Companies run by the founding family are significantly less inclined towards earnings management practices because of the huge reputational capital invested in the business (Jiraporn and DaDalt 2009).

Consistently, the results of Martin et al. (2016) show that family businesses, being particularly worried about the possible reputational damage deriving from unethical behaviour, are less likely to manipulate profits than their non-family counterparts. Furthermore, the moderating effect of family ownership, unlike what is reported by Stockmans et al. (2010), is particularly evident when the company is managed by the founder as he/she is committed to passing on to descendants a business with a solid reputation. In fact, empirical studies have found that family businesses are subject to less reputational damage due to accounting manipulations than non-family members as the former have more incentives to control management behaviour, reduce asymmetric information and, in so doing, the earnings management and the consequent damage to the company image (Rodriguez-Ariza et al. 2016).

Empirical literature indicates that visibility, in terms of company size, reduces earnings management practices as it amplifies reputational damage in the event that the manipulation is discovered (Gottardo and Moisello 2019). Previous research indicates that non-financial disclosure quality is positively affected by media exposure (Branco and Rodrigues 2008) and, in particular, the effect of financial press exposure is more significant for family than non-family businesses, as the former are particularly concerned with the effect of visibility on reputation (Gavana et al. 2017b). There is also evidence that companies that manage earnings tend to engage significantly in communicating their social and environmental performance; this behaviour is strengthened by the visibility of the company and the effect is stronger in family than non-family businesses (Gavana et al. 2017a).

R.Q.: Which forms of visibility influence earnings management in family and non-family businesses?

\section{Methodology}

We analyse a sample of 172 companies listed on the Italian Stock Exchange in 2017. Financial companies such as banks and insurance companies were excluded due to their regulatory peculiarities. The balance sheet data required for the analyses refer to the period 2007-2017 and have been downloaded from Orbis, the governance and ownership structure data were hand-collected, cross-checking the information provided by Orbis, the Italian Stock Exchange and CONSOB websites.

The proxy used to evaluate earnings quality is given by discretionary accruals, these are measured in absolute value and have been calculated using the Jones model modified in the cross-sectional version (Dechow et al. 1995; Bartov et al. 2000; Peasnell et al. 2000; Subramanyam 1996; DeFond and Jiambalvo 1994).

In particular the discretional accruals are calculated as the difference between the total and the non-discretionary ones, where total accruals are given by:

$$
\mathrm{TAi}, \mathrm{t}=\Delta \mathrm{CAi}, \mathrm{t}-\Delta \mathrm{CCEi}, \mathrm{t}-\Delta \mathrm{CLi}, \mathrm{t}+\Delta \mathrm{STDi}, \mathrm{t}-\mathrm{DAEi}, \mathrm{t}
$$

where:

TAi, $\mathrm{t}=$ total accruals

$\Delta \mathrm{CAi}, \mathrm{t}=$ variation in current asset between period $\mathrm{t}$ and $\mathrm{t}-1$

$\triangle \mathrm{CCEi}, \mathrm{t}=$ change in cash and cash equivalents between period $\mathrm{t}$ and $\mathrm{t}-1$

$\Delta \mathrm{CLi}, \mathrm{t}=$ variation in current liabilities between period $\mathrm{t}$ and $\mathrm{t}-1$

$\Delta S T D i, t=$ variation in short term debts included in current liabilities between period $t$ and $t-1$ 
$\mathrm{DAEi}, \mathrm{t}=$ depreciation and amortization expenses

Non-discretionary accruals are calculated by estimating for each sector with at least ten companies with usable data the following cross-sectional model:

$\mathrm{TAi}, \mathrm{t} / \mathrm{Ai}, \mathrm{t}-1=\alpha 0+\alpha 1(1 / \mathrm{Ai}, \mathrm{t}-1)+\alpha 2[(\Delta \mathrm{REVi}, \mathrm{t}-\Delta \mathrm{RECi}, \mathrm{t}) / \mathrm{Ai}, \mathrm{t}-1]+\alpha 3(\mathrm{PPEi}, \mathrm{t} / \mathrm{Ai}, \mathrm{t}-1)+\varepsilon \mathrm{i}, \mathrm{t}$

where:

Ai, $t-1=$ lagged total assets

$\triangle \mathrm{REVi}, \mathrm{t}=$ variation in revenues between period $\mathrm{t}$ and $\mathrm{t}-1$

$\triangle \mathrm{RECi}, \mathrm{t}=$ variation in trade receivables between period $\mathrm{t}$ and $\mathrm{t}-1$

$\mathrm{PPEi}, \mathrm{t}=$ gross property, plant and equipment

The coefficients estimated in the model (2) are then applied to estimate the non-discretionary accruals of the $\mathrm{i}$-th enterprise in the period $\mathrm{t}$ :

$$
\text { NDAi, } \mathrm{t} / \mathrm{Ai}, \mathrm{t}-1=\mathrm{a} 0+\mathrm{a} 1(1 / \mathrm{Ai}, \mathrm{t}-1)+\mathrm{a} 2[(\triangle \mathrm{REVi}, \mathrm{t}-\Delta \mathrm{RECi}, \mathrm{t}) / \mathrm{Ai}, \mathrm{t}-1]+\mathrm{a} 3(\mathrm{PPEi}, \mathrm{t} / \mathrm{Ai}, \mathrm{t}-1)
$$

The discretionary accruals are then calculated as the difference between total and non-discretionary accruals in absolute terms:

$$
D A i, t=|T A i, t-N D A i, t|
$$

To analyse the link between ownership structure, visibility and earnings management, we take into consideration a series of control variables: family control, state control, amount of sales, exposure to the media, proximity to consumers, assets, firm age, leverage, profitability, industry and time effects.

In this study, a business is defined as 'family' if the ultimate owner is a family that owns at least $20 \%$ of the ordinary shares and if the CEO is a family member. The threshold used in the literature in the case of listed firms ranges from $5 \%$ to $25 \%$ and $20 \%$ is consistent with empirical literature on Italian listed firms (Faccio and Lang 2002; Franks et al. 2009; Ellul et al. 2010; Croci et al. 2011). Family control (DFamily) is a binary variable which takes value one if a firm corresponds to the above requirements. Similarly, we use a dummy variable (DPublic) in order to indicate state-owned firms.

The impact of visibility is analysed using four proxies, two variables of size given by sales and invested capital, exposure to the media (MediaEx) and proximity to consumers (ConProx). Sales are given by the natural logarithm of the sales value in each year. The activities are given by the natural logarithm of the total assets. The exposure to the media is measured by the number of articles that appeared in the Sole 24 Ore-the most renowned Italian financial daily newspaper-in each year (Gavana et al. 2017b). Proximity to consumers is a binary variable that has a value equal to one if the company is well known to final consumers as they directly use the products and/or services: that is, firms operating in the telecommunications, textiles and clothing sectors, personal and household products, food and beverages, pharmaceuticals, utilities in the electricity, gas and water sectors have these characteristics (Branco and Rodrigues 2008; Gavana et al. 2018). Firm age (Age) is measured as the log of the number of years since a firm's foundation, and, following Kong et al. (2017), we use it as a measure of public visibility. The leverage is represented by the ratio between financial payables and equity measured at book values. Profitability is measured with the $R O A$ of year $\mathrm{t}-1$. To control for industry fixed effects we add industry dummy variables to our model using the Nace rev. 2 codes to classify the sample firms in ten industries. To deal with possible time effects we also introduce year dummies in the panel model.

We implement an explanatory model as follows:

$$
\mathrm{DAi}, \mathrm{t}=\beta 0+\sum \beta \mathrm{j} X \mathrm{j}, \mathrm{i}, \mathrm{t}+\sum \beta \mathrm{kXk,i,t}+\sum \beta 1 X 1, \mathrm{i}, \mathrm{t}+\varepsilon \mathrm{i}, \mathrm{t}
$$


where:

$\mathrm{DA}=$ discretionary accruals

$\mathrm{X}, \mathrm{i}, \mathrm{t}=$ controlling owner nature variables

$\mathrm{Xk}, \mathrm{i}, \mathrm{t}=$ visibility variables

$\mathrm{Xl}, \mathrm{i}, \mathrm{t}=$ control variables

To incorporate the possible interaction effects between family nature of the firm and visibility, we implement an augmented model for each visibility variable (Media exposure, Assets, Sales, Consumer proximity and Age) as follows:

$$
\mathrm{DAi}, \mathrm{t}=\beta 0+\sum \beta \mathrm{j} X \mathrm{j}, \mathrm{i}, \mathrm{t}+\sum \beta \mathrm{kXk}, \mathrm{i}, \mathrm{t}+\sum \beta 1 \mathrm{Xl}, \mathrm{i}, \mathrm{t}+\beta \mathrm{w} \text { Interaction variable }+\varepsilon \mathrm{i}, \mathrm{t}
$$

The above models are estimated using panel OLS with time and industry fixed effects to account for differences across industries and years.

\section{Results and Discussion}

Table 1 shows the descriptive statistics of the variables taken into consideration for the entire sample and separately for the family firms, publicly and private owned non-family businesses.

Table 1. Descriptive Statistics.

\begin{tabular}{cccc}
\hline & $\begin{array}{c}\text { Publicly Owned } \\
\text { Non-Family Firms }\end{array}$ & $\begin{array}{c}\text { Privately Owned } \\
\text { Non-Family Firms }\end{array}$ & Family Firms \\
\hline Discretionary Accruals & $0.07(0.06)$ & $0.10(0.12)$ & $0.08(0.07)$ \\
Age & $3.47(0.76)$ & $3.26(0.83)$ & $3.46(0.67)$ \\
MediaEx & $3.17(1.78)$ & $1.08(1.32)$ & $1.34(1.43)$ \\
Leverage & $0.85(1.87)$ & $1.04(2.00)$ & $1.12(1.96)$ \\
ROAt - & $3.99(7.37)$ & $1.91(11.72)$ & $4.73(8.56)$ \\
Sales & $14.32(2.38)$ & $10.89(2.24)$ & $11.77(2.25)$ \\
ConProx & $0.48(0.50)$ & $0.22(0.41)$ & $0.33(0.47)$ \\
Assets & $15.51(2.17)$ & $11.99(1.91)$ & $12.55(1.79)$ \\
\hline
\end{tabular}

The data show that publicly owned non-family business and family companies are, on average, older than non-family firms and indicate a greater exposure to the media of state-owned firms. The leverage value is slightly higher for family businesses and these are also much more profitable, confirming the results reported in Anderson's studies and Anderson and Reeb (2003b); Andres (2008) and Barontini and Caprio (2006).

The average asset value is higher for state-controlled firms whilst it is substantially the same for family and non-family companies. We find a greater propensity of state-owned and family firms to operate in sectors close to consumers. Finally, as regards earnings quality, publicly-owned and family businesses make less use of discretionary accruals than non-family companies as indicated by the correlations analysis results (Table 2). State owned companies' low propensity to manipulate earnings confirms that these firms engage in demonstrating that they operate in the public interest, as previously pointed out by research on non-financial disclosure strategies (Cormier and Gordon 2001). These results are also consistent with the reputational concerns suggested by quite recent literature on family firms' earnings quality (Pazzaglia et al. 2013; Gavana et al. 2017a). 
Table 2. Correlations.

\begin{tabular}{|c|c|c|c|c|c|c|c|c|c|}
\hline & Discretionary Accruals & Sales & Assets & ConProx & MediaEx & DFamily & DPublic & Age & Leverage \\
\hline Sales & $-0.22^{* * *}$ & & & & & & & & \\
\hline Assets & $-0.16^{* * *}$ & $0.78^{* * *}$ & & & & & & & \\
\hline ConProx & $-0.10^{* * *}$ & $0.18^{* * *}$ & $0.11^{* * *}$ & & & & & & \\
\hline MediaEx & $-0.05^{* *}$ & $0.49 * * *$ & $0.67^{* * *}$ & $0.13^{* * *}$ & & & & & \\
\hline DFamily & $-0.06^{* * *}$ & $0.05^{* *}$ & -0.01 & $0.08^{* * *}$ & -0.03 & & & & \\
\hline DPublic & $-0.08^{* * *}$ & $0.37^{* * *}$ & $0.44^{* * *}$ & $0.15^{* * *}$ & $0.37^{* * *}$ & $-0.21^{* * *}$ & & & \\
\hline Age & $-0.11^{* * *}$ & $0.18^{* * *}$ & $0.27 * * *$ & $-0.13^{* * *}$ & $-0.06^{* * *}$ & $0.09 * * *$ & $0.04 *$ & & \\
\hline Leverage & -0.00 & $-0.05 *$ & $-0.07^{* *}$ & $0.06^{* * *}$ & $-0.10^{* * *}$ & 0.03 & -0.04 & $-0.06^{* * *}$ & \\
\hline ROAt -1 & $-0.07^{* * *}$ & $0.23^{* * *}$ & $0.12^{* * *}$ & $0.12^{\text {*** }}$ & $0.13^{* * *}$ & $0.12 * * *$ & 0.04 & $-0.06^{* *}$ & $-0.11^{* * *}$ \\
\hline
\end{tabular}

Table 3 shows the results of the regression analysis made on our data using panel OLS with time and industry fixed effects to account for differences across industries and years.

Table 3. OLS pooling regressions with time and industry fixed effects.

\begin{tabular}{|c|c|c|c|c|c|c|}
\hline & Model 1 & Model 2 & Model 3 & Model 4 & Model 5 & Model 6 \\
\hline Intercept & $0.22 * * *$ & $0.22 * * *$ & $0.21 * * *$ & $0.21 * * *$ & $0.22 * * *$ & $0.21 * * *$ \\
\hline Sales & $-0.01 * * *$ & $-0.01 * * *$ & $-0.01 * * *$ & $-0.01 * * *$ & $-0.01 * * *$ & $-0.01^{* * *}$ \\
\hline Assets & -0.00 & -0.00 & -0.00 & -0.00 & -0.00 & -0.00 \\
\hline ConProx & $-0.01 *$ & $-0.01 *$ & $-0.01 * *$ & $-0.01 *$ & $-0.01 *$ & $-0.01 *$ \\
\hline MediaEx & $0.00 * *$ & $0.00 * *$ & $0.00 * *$ & $0.00 * *$ & $0.00 * *$ & $0.00 * *$ \\
\hline DFamily & $-0.01^{* * *}$ & $-0.01 *$ & -0.01 & -0.01 & $-0.01 * * *$ & 0.01 \\
\hline DPublic & -0.01 & -0.01 & -0.01 & -0.01 & -0.01 & -0.01 \\
\hline Age & $-0.01 * * *$ & $-0.01^{* * *}$ & $-0.01 * * *$ & $-0.01^{* * *}$ & $-0.01 * * *$ & $-0.01^{* * *}$ \\
\hline Leverage & -0.00 & -0.00 & -0.00 & -0.00 & -0.00 & -0.00 \\
\hline ROAt -1 & -0.00 & -0.00 & -0.00 & -0.00 & -0.00 & -0.00 \\
\hline MediaEx*DFamily & & -0.00 & & & & \\
\hline Assets*DFamily & & & -0.00 & & & \\
\hline Sales*DFamily & & & & -0.00 & & \\
\hline $\begin{array}{c}\text { ConProx*DFamily } \\
\text { Age }^{*} \text { DFamily }\end{array}$ & & & & & 0.01 & -0.01 \\
\hline Year dummies & yes & yes & yes & yes & yes & yes \\
\hline Industry dummies & yes & yes & yes & yes & yes & yes \\
\hline $\mathrm{R}^{2}$ & 0.10 & 0.10 & 0.10 & 0.10 & 0.10 & 0.10 \\
\hline $\mathrm{N}^{\circ}$ obs. & 1729 & 1729 & 1729 & 1729 & 1729 & 1729 \\
\hline
\end{tabular}

In all the models the dependent variable is given by discretionary accruals in absolute value, this is our proxy for earnings management. Model 1 controls for the effect of different forms of visibility and of the nature of the controlling owner (DFamily and DPublic) on the absolute value of discretionary accruals. The following models control for interaction effects between family nature of the firm and different types of visibility: media exposure (Model 2), assets (Model 3), sales (Model 4), consumer proximity (Model 5) and age (Model 6). The first model evidence indicates that family control has a significant negative effect on the absolute value of discretionary accruals. The regression analysis results show, in each model, that firm's size, in terms of sales, as well as belonging to a sector close to the consumer (ConProx) reduce the absolute value of discretionary accruals. The findings indicate that this value is also significantly reduced by the effect of firm age. Conversely, financial press exposure (MediaEx) enhances the aforementioned value. When we introduce the interactions between family control and media exposure and between family control and consumer proximity, the dummy for family control maintains a significant negative effect on absolute discretionary accruals. It is not significant when we control for the interaction between family control and size, measured in terms of assets as well as of sales and for the interaction between family control and age.

The findings of the analysis suggest that the level of company visibility tends to have an effect on earnings quality but the effect is different depending on the type of visibility. Companies closest to consumers show a lower propensity to manipulate earnings, as moderated by the fear that a scandal 
linked to unethical behaviour may have direct repercussions on the reputation of the company and the value attributed to the product by consumers. Similarly, greater visibility given by the size or age of the company moderates the earnings management practices as it amplifies the extent of reputational damage in the event that the earnings management is identified. The opposite effect is instead given by the visibility of the company in the financial press. This effect can be explained as the result of the analysis of potential costs and benefits deriving from earnings management practices. The costs are linked to the potential reputational damage resulting from a strong visibility in the financial press. The benefits derive from the greater resonance that the manipulated profit, if not discovered, can have on the investors through the specialized press (Gottardo and Moisello 2019).

Family businesses, in line with previous literature, show a lower level of earnings management (Ali et al. 2007; Martin et al. 2016; Gavana et al. 2017a). Family control reduces earnings management as pointed out by model 1 , model 2 and 5 where we control, respectively, for the combined effect of family ownership with visibility in the financial press and proximity to the consumer. The beneficial effect of age on earnings quality is not increased by family control. It is not surprising because as firm age increases the generational effect intervenes. The exposure to the financial press is a form of visibility to investors and the result of the analysis is consistent and helps to explain the confidence of private equity firms in family businesses suggested by the literature (Ahlers et al. 2017), as well as trust towards the family-controlled businesses recorded among non-professional investors (Lude and Prügl 2019). On the other hand, the effect of family control is also significant in concomitance with proximity to the consumer, suggesting that family businesses are aware of the fact that the consumer has particular expectations about not only social but also economic and financial behaviour on the part of the family business, as evidenced by the literature (Binz et al. 2013).

Family businesses enjoy greater consumer confidence and this advantage derives from the consumer's humanization of the brand (Beck and Prüg1 2018), so unethical behaviour by the company, such as the manipulation of profits, has a potentially destructive effect on trust and on the conditions of existence of the company system. The best quality of family businesses' financial disclosure is linked to the will to preserve the stock and the flows of socio-emotional returns that family members derive from the business. The image of the family is closely linked to that of the company, given the strong sense of identification (Berrone et al. 2012), so a scandal linked to the manipulation of earnings would stain the image of the family and of the individuals that belong to it. Previous studies suggest that family businesses tend to limit behaviour aimed at expropriating minority shareholders because they fear reputational effects (Feng 2011). Our study extends these results because it highlights that family firms are less prone to manipulate earnings than non-family companies, also when we control for the effect of exposure on the financial press. Furthermore, earnings management practices can damage the relationships between the controlling family and external investors, not only in terms of minority shareholders but also in terms of debt financiers. Lenders' trust could be reduced and they could put in place strict constraints such as the presence of non-family members on the board of directors. This would limit a very important dimension of socioemotional wealth, that is, family direct influence on the business. The manipulation of profits can generate legal disputes with shareholders, with heavy repercussions in terms of the reputation of the company and of the family since the former, given the deep sense of identification, is seen as the mirror image of the second (Zellweger et al. 2012). This would also jeopardize other important dimensions of socioemotional wealth as it could also negatively influence the quality of the social ties that, on the one hand, family members have developed within the company with those who do not belong to the family, and, on the other hand, between the company and the family members and the external stakeholders.

\section{Conclusions}

This article investigated the effect of different forms of visibility on the earnings quality of family and non-family businesses through a longitudinal analysis of a sample of non-financial listed companies. The results show that visibility can have opposite effects on the practices of manipulation 
of profits and also that the family control of a business has important lowering effects on these non-ethical practices. The manipulation of profits can derive from four different types of agency conflict: management versus shareholders (first type), majority shareholders versus minority shareholders (second type), company versus bearers of debt capital (third type) and company versus state (fourth type). The majority shareholders of family businesses have strong incentives, both in economic and socio-emotional terms, to control management decisions and to avoid information asymmetries and this reduces earnings management linked to the first type of conflict. The desire to maintain the family's control and influence over the business and the strong interest in the reputation of the company, reduce the manipulation of profits linked to the third type of agency problem. The relevance of the reputational aspects, linked to the strong identification between the controlling family and the company, moderates the earnings management linked to the second and fourth type of conflict as it could generate the loss of economic and socio-emotional returns that family members derive from the image of the business and the bonds of trust established with internal and external stakeholders. For this reason, the positive effect of family ownership on the quality of profits is particularly significant in the presence of high visibility of the business for the consumer and the financial press.

Our findings have practical implications as they are of interest for investors given the potential effect of earnings quality on their investment performance.

This study has limits because it explores the effects of different forms of visibility, distinguishing between family and non-family businesses, without highlighting possible differences within the family business. The latter is not a homogeneous entity but is characterized by a significant heterogeneity linked, for example, to the characteristics of the board, the CEO, to the presence of the founder and to the generational stage of the company. Therefore, future studies could focus on the relationship between visibility and earnings management within family businesses. Moreover, since various institutional aspects can influence earnings management, it would be useful to extend the analysis by applying it to an international sample of companies operating in different countries.

Author Contributions: G.G., P.G. and A.M.M. conceived and designed the study; G.G., P.G. and A.M.M. constructed the database and analysed the data; G.G., P.G. and A.M.M. contributed analyses tools; G.G., P.G. and A.M.M. wrote the paper.

Funding: This research received no external funding

Conflicts of Interest: The authors declare no conflict of interest.

\section{References}

Abdolmohammadi, Mohammad, Erlend Kvaal, and John Christian Langli. 2010. Earnings Management Priorities of Private Family Firms. CCGR Working Paper 3/2010. Oslo: BI Norwegian Business School.

Achleitner, Ann Kristin, Nina Günther, Chistoph Kaserer, and Gianfranco Siciliano. 2014. Real earnings management and accrual-based earnings management in family firms. European Accounting Review 23: 431-61. [CrossRef]

Ahlers, Oliver, Andres Hack, Kristen Madison, Mike Wright, and Franz W. Kellermanns. 2017. Is it All About Money? Affective Commitment and the Difference Between Family and Non-family Sellers in Buyouts. British Journal of Management 28: 159-79. [CrossRef]

Ali, Ashiq, Tai-Yuan Chen, and Suresh Radhakrishnan. 2007. Corporate disclosures by family firms. Journal of Accounting and Economics 44: 238-86. [CrossRef]

Anderson, Ronald C., and David M. Reeb. 2003a. Founding-family ownership, corporate diversification and firm leverage. Journal of Law and Economics 46: 653-84. [CrossRef]

Anderson, Ronald C., and David M. Reeb. 2003b. Founding-family ownership and firm performance: Evidence from the S\&P 500. Journal of Finance 58: 1301-28.

Anderson, Ronald C., Sattar A. Mansi, and David M. Reeb. 2003. Founding family ownership and the agency cost of debt. Journal of Financial economics 68: 263-85. [CrossRef]

Andres, Chistian. 2008. Large shareholders and firm performance: An empirical examination of founding-family ownership. Journal of Corporate Finance 14: 431-45. [CrossRef] 
Astrachan, Joseph C., and Peter Jaskiewicz. 2008. Emotional returns and emotional costs in privately held family businesses: Advancing traditional business valuation. Family Business Review 21: 139-49. [CrossRef]

Barontini, Roberto, and Lorenzo Caprio. 2006. The Effect of Family Control on Firm Value and Performance: Evidence from Continental Europe. European Financial Management 12: 689-723. [CrossRef]

Bartov, Eli, Ferdinand A. Gul, and Judy S. Tsui. 2000. Discretionary-accruals models and audit qualifications. Journal of Accounting and Economics 30: 421-52. [CrossRef]

Beasley, Mark S. 1996. An empirical analysis of the relation between the board of director composition and financial statement fraud. Accounting Review, 443-65.

Beck, Susanne, and Reinhard Prügl. 2018. Family firm reputation and humanization: Consumers and the trust advantage of family firms under different conditions of brand familiarity. Family Business Review 31: 460-82. [CrossRef]

Becker, Connie L., Mark L. DeFond, James Jiambalvo, and K. R. Subramanyam. 1998. The effect of audit quality on earnings management. Contemporary Accounting Research 15: 1-24. [CrossRef]

Bédard, Jean, Sonda M. Chtourou, and Lucie Courtea. 2004. The effect of audit committee expertise, independence and activity on aggressive earnings management. Auditing: A Journal of Practice $\mathcal{E}$ Theory 23: 13-35.

Bergstresser, Daniel, and Thomas Philippon. 2006. CEO incentives and earnings management. Journal of Financial Economics 80: 511-29. [CrossRef]

Berrone, Pascual, Cristina Cruz, Luis R. Gómez-Mejía, and Martin Larraza-Kintan. 2010. Socioemotional wealth and corporate responses to institutional pressures: Do family-controlled firms pollute less? Administrative Science Quarterly 55: 82-113. [CrossRef]

Berrone, Pascual, Cristina Cruz, and Luis R. Gómez-Mejía. 2012. Socioemotional wealth in family firms: Theoretical dimensions, assessment approaches and agenda for future research. Family Business Review 25: 258-79. [CrossRef]

Binz, Claudia, Joseph F. Hair Jr., Torsten M. Pieper, and Artur Baldauf. 2013. Exploring the effect of distinct family firm reputation on consumers' preferences. Journal of Family Business Strategy 4: 3-11. [CrossRef]

Branco, Manuel Castelo, and Lucia Lima Rodrigues. 2008. Factors influencing social responsibility disclosure by Portuguese companies. Journal of Business Ethics 83: 685-701. [CrossRef]

Carney, Michael. 2005. Corporate governance and competitive advantage in family-controlled firms. Entrepreneurship Theory and Practice 29: 249-65. [CrossRef]

Chen, Shuping, Xia Chen, Qiang Cheng, and Terry Shevlin. 2010. Are family firms more tax aggressive than non-family firms? Journal of Financial Economics 95: 41-61. [CrossRef]

Chi, Chin-Weng, Ken Hung, Hui-Weng Cheng, and Pang-Tien Lieu. 2015. Family firms and earnings management in Taiwan: Influence of corporate governance. International Review of Economics E Finance 36: 88-98.

Chih, Hsiang-Lin, Chung-Hua Shen, and Feng-Ching Kang. 2008. Corporate social responsibility, investor protection and earnings management: Some international evidence. Journal of Business Ethics 79: 179-98. [CrossRef]

Chrisman, James J., Jess H. Chua, and Reginald A. Litz. 2004. Comparing the agency costs of family and non-family firms: Conceptual issues and exploratory evidence. Entrepreneurship Theory and Practice 28: 335-54. [CrossRef]

Chua, James H., Jess J. Chrisman, and Alfredo De Massis. 2015. A closer look at socioemotional wealth: Its flows, stocks and prospects for moving forward. Entrepreneurship Theory and Practice 39: 173-82. [CrossRef]

Chung, Richard, Michael Firth, and Jeong-Bon Kim. 2002. Institutional monitoring and opportunistic earnings management. Journal of Corporate Finance 8: 29-48. [CrossRef]

Corbetta, Guido, and Alessandro Minichill. 2005. 11 Governo delle Imprese Italiane Quotate a Controllo Familiare: I Risultati di una Ricerca Esplorativa. Economia \& Management 6: 59-77.

Cormier, Denis, and Irene M. Gordon. 2001. An examination of social and environmental reporting strategies. Accounting, Auditing \& Accountability Journal 14: 587-617.

Croci, Ettore, John A. Doukas, and Halit Gonec. 2011. Family control and financing decisions. European Financial Management 17: 860-97. [CrossRef]

Cruz, Cristina, Martin Larraza-Kintana, Lucia Garcés-Galdeano, and Pascual Berrone. 2014. Are family firms really more socially responsible? Entrepreneurship Theory and Practice 38: 1295-316. [CrossRef] 
Cuadrado-Ballesteros, Beatriz, Lázaro Rodríguez-Ariza, and Isabel-María García-Sánchez. 2015. The role of independent directors at family firms in relation to corporate social responsibility disclosures. International Business Review 24: 890-901. [CrossRef]

Davidson, Ryan, Jenny Goodwin-Stewart, and Pamela Kent. 2005. Internal governance structures and earnings management. Accounting \& Finance 45: 241-67.

Dechow, Patricia M., Richard G. Sloan, and Amy P. Sweeney. 1995. Detecting earnings management. Accounting Review 70: 193-225.

DeFond, Mark L., and James Jiambalvo. 1994. Debt covenant violation and manipulation of accruals. Journal of Accounting and Economics 17: 145-76. [CrossRef]

Dyer, W. Gibb, Jr., and David A. Whetten. 2006. Family firms and social responsibility: Preliminary evidence from the S\&P 500. Entrepreneurship Theory and Practice 30: 785-802.

Ellul, Andrew, Marco Pagano, and Fausto Panunzi. 2010. Inheritance Law and Investment in Family Firms. American Economic Review 100: 2414-50. [CrossRef]

Faccio, Mara, and Larry H. P. Lang. 2002. The ultimate ownership of Western Europe corporations. Journal of Financial Economic 65: 365-95. [CrossRef]

Feng, Xu'nan. 2011. Dividends and tunneling: Evidence from family firms in China. China Finance Review International 1: 152-67.

Franks, Julian, Colin Mayer, Paolo Volpin, and Hannes F. Wagner. 2009. The Life Cycle of Family Ownership; a Comparative Study of France, Germany, Italy and U.K.. Working Paper. London: London Business School.

Gavana, Giovanna, Pietro Gottardo, and Anna M. Moisello. 2017a. Earnings management and CSR disclosure. Family versus. non-family firms. Sustainability 9: 2327. [CrossRef]

Gavana, Giovanna, Pietro Gottardo, and Anna M. Moisello. 2017b. Sustainability reporting in family firms: A panel data analysis. Sustainability 9: 38. [CrossRef]

Gavana, Giovanna, Gottardo Pietro, and Anna Moisello. 2018. Do Customers Value CSR Disclosure? Evidence from Italian Family and Non-Family Firms. Sustainability 10: 1642. [CrossRef]

Gómez-Mejía, Luis R., Katalin Tákas Haynes, Manuel Nunez-Nickel, Kathim J. L. Jacobson, and José Moyano-Fuentes. 2007. Socioemotional wealth and business risks in family-controlled firms: Evidence from Spanish olive oil mills. Administrative Science Quarterly 52: 106-37. [CrossRef]

Gómez-Mejía, Luis R., Cristina Cruz, Pascual Berrone, and Julio De Castro. 2011. The bind that ties: Socioemotional wealth preservation in family firms. Academy of Management Annals 5: 653-707. [CrossRef]

Goncharov, Igor, and Jochen Zimmermann. 2006. Earnings management when incentives compete: The role of tax accounting in Russia. Journal of International Accounting Research 5: 41-65. [CrossRef]

Gottardo, Pietro, and Anna M. Moisello. 2019. Equity and Bond Issues and Earnings Management Practices. In Capital Structure, Earnings Management and Risk of Financial Distress. Cham: Springer, pp. 57-73.

Graham, John R., Campbell R. Harvey, and Shiva Rajgopal. 2005. The economic implications of corporate financial reporting. Journal of Accounting and Economics 40: 3-73. [CrossRef]

Hillier, David, Beatriz Martínez, Pankaj C. Patel, Julio Pindado, and Ignacio Requejo. 2018. Pound of flesh? Debt contract strictness and family firms. Entrepreneurship Theory and Practice 42: 259-82. [CrossRef]

Hölmstrom, Bengt. 1979. Moral hazard and observability. Bell Journal of Economics 10: 74-91. [CrossRef]

Jaggi, Bikki, and Sidney Leung. 2007. Impact of family dominance on monitoring of earnings management by audit committees: Evidence from Hong Kong. Journal of International Accounting, Auditing and Taxation 16: 27-50. [CrossRef]

Jaggi, Bikki, Sidney Leung, and Ferdinand Gul. 2009. Family control, board independence and earnings management: Evidence based on Hong Kong firms. Journal of Accounting and Public Policy 28: 281-300. [CrossRef]

Jensen, Michael C., and William H. Meckling. 1976. Theory of the firm: Managerial behavior, agency costs and ownership structure. Journal of Financial Economics 3: 305-60. [CrossRef]

Jiraporn, Pornsit, and Peter J. DaDalt. 2009. Does founding family control affect earnings management? Applied Economics Letters 16: 113-19. [CrossRef]

Kao, Lanfeng, and Anlin Chen. 2004. The effects of board characteristics on earnings management. Corporate Ownership \& Control 1: 96-107.

Klein, April. 2002. Audit committee, board of director characteristics and earnings management. Journal of Accounting and Economics 33: 375-400. [CrossRef] 
Kong, Xiangting, Suresh Radhakrishnan, and Albert Tsang. 2017. Corporate Lobbying, Visibility and Accounting Conservatism. Journal of Business Finance \& Accounting 44: 527-57.

La Porta, Rafael, Florencio Lopez-de-Silanes, and Andrei Shleifer. 1999. Corporate ownership around the world. Journal of Finance 54: 471-517. [CrossRef]

Lude, Maximillian, and Reinhard Prügl. 2019. Risky decisions and the family firm bias: An experimental study based on prospect theory. Entrepreneurship Theory and Practice, 1042258718796078. [CrossRef]

Martin, Geoffrey, Joanne T. Campbell, and Luis Gomez-Mejia. 2016. Family control, socioemotional wealth and earnings management in publicly traded firms. Journal of Business Ethics 133: 453-69. [CrossRef]

Mauer, David C., and Sudipto Sarkar. 2005. Real options, agency conflicts and optimal capital structure. Journal of Banking E Finance 29: 1405-28.

Mella, Piero, and Patrizia Gazzola. 2015. Ethics builds reputation. International Journal of Markets and Business Systems 1: 38-52. [CrossRef]

Paiva, Inna Sousa, Isabel Costa Lourenço, and Manuel Castelo Branco. 2016. Earnings management in family firms: Current state of knowledge and opportunities for future research. Review of Accounting and Finance 15: 85-100. [CrossRef]

Pazzaglia, Federica, Stefano Mengoli, and Elena Sapienza. 2013. Earnings quality in acquired and non-acquired family firms: A socioemotional wealth perspective. Family Business Review 26: 374-86. [CrossRef]

Peasnell, Ken V., Peter F. Pope, and Steven Young. 2000. Detecting earnings management using cross-sectional abnormal accruals models. Accounting and Business Research 30: 313-26. [CrossRef]

Prencipe, Annalisa, and Sasson Bar-Yosef. 2011. Corporate governance and earnings management in family-controlled companies. Journal of Accounting, Auditing E Finance 26: 199-227.

Prencipe, Annalisa, Garen Markarian, and Lorenzo Pozza. 2008. Earnings management in family firms: Evidence from R\&D cost capitalization in Italy. Family Business Review 21: 71-88.

Rajgopal, Shivaram, Terry Shevlin, and Mohan Venkatachalam. 2003. Does the stock market fully appreciate the implications of leading indicators for future earnings? Evidence from order backlog. Review of Accounting Studies 8: 461-92. [CrossRef]

Rangan, Srinivasan. 1998. Earnings management and the performance of seasoned equity offerings. Journal of Financial Economics 50: 101-22. [CrossRef]

Rodriguez-Ariza, Lázaro, Jennifer Martínez-Ferrero, and Manuel Bermejo-Sánchez. 2016. Consequences of earnings management for corporate reputation: Evidence from family firms. Accounting Research Journal 29: 457-74. [CrossRef]

Romano, Claudio A., George A. Tanewsky, and Kosmas X. Smyrnios. 2001. Capital structure decision making: A model for family business. Journal of Business Venturing 16: 285-310. [CrossRef]

Schipper, Katherine. 1989. Earnings management. Accounting Horizons 3: 91-102.

Shleifer, Andrei, and Robert W. Vishny. 1986. Large shareholders and corporate control. Journal of Political Economy 94: 461-88. [CrossRef]

Steijvers, Tensie, Wim Voordeckers, and Koen Vanhoof. 2010. Collateral, relationship lending and family firms. Small Business Economics 34: 243-59. [CrossRef]

Stockmans, Annelies, Nadine Lybaert, and Wim Voordeckers. 2010. Socioemotional wealth and earnings management in private family firms. Family Business Review 23: 280-94. [CrossRef]

Subramanyam, K. R. 1996. The pricing of discretionary accruals. Journal of Accounting and Economics 22: $249-81$. [CrossRef]

Teoh, Siew H., Ivo Welch, and T. J. Wong. 1998. Earnings management and the underperformance of seasoned equity offerings. Journal of Financial Economics 50: 63-99. [CrossRef]

Tiscini, Riccardo, and Francesca Di Donato. 2006. The Relation between Accounting Frauds and Corporate Governance Systems: An Analysis of Recent Scandals. Available online: http://unpan1.un.org/intradoc/ groups/public/documents/apcity/unpan033868.pdf (accessed on 5 November 2018).

Tiscini, Riccardo, and Francesca Di Donato. 2013. The effects of family involvement and corporate governance practices on earnings quality of listed companies. In Handbook of Research on Family Business, 2nd ed. Cheltenham: Edward Elgar, pp. 65-81.

Villalonga, Belen, and Raphael Amit. 2006. How do family ownership, control and management affect firm value? Journal of Financial Economics 80: 385-417. [CrossRef] 
Walker, Martin. 2013. How far can we trust earnings numbers? What research tells us about earnings management. Accounting and Business Research 43: 445-81. [CrossRef]

Wang, Dechun. 2006. Founding family ownership and earnings quality. Journal of Accounting Research 44: 619-56. [CrossRef]

Xie, Biao, Wallace N. Davidson III, and Peter J. DaDalt. 2003. Earnings management and corporate governance: The role of the board and the audit committee. Journal of Corporate Finance 9: 295-316. [CrossRef]

Yang, Mei-Ling. 2010. The impact of controlling families and family CEOs on earnings management. Family Business Review 23: 266-79. [CrossRef]

Yeo, Gillian H., Patricia M. Tan, Kim Wai Ho, and Sheng-Syang Chen. 2002. Corporate ownership structure and the informativeness of earnings. Journal of Business Finance $\mathcal{E}$ Accounting 29: 1023-46.

Zellweger, Thomas M., Frank W. Kellermanns, James J. Chrisman, and Jess H. Chua. 2011. Family Control and Family Firm Valuation by Family CEOs: The Importance for Intentions for Transgenerational Control. Organization Science 23: 851-68. [CrossRef]

Zellweger, Thomas M., Franz W. Kellermanns, Kimberly A. Eddleston, and Esra Memili. 2012. Building a family firm image: How family firms capitalize on their family ties. Journal of Family Business Strategy 3: 239-50. [CrossRef]

(C) 2019 by the authors. Licensee MDPI, Basel, Switzerland. This article is an open access article distributed under the terms and conditions of the Creative Commons Attribution (CC BY) license (http:/ / creativecommons.org/licenses/by/4.0/). 